\title{
Considerações sobre a evolução do Sistema Nacional de Unidades de Conservação e o ordenamento territorial da Amazônia: interações entre o Estado e a Ciência
}

\section{Considerations on the Evolution of the National System of Protected Areas and the Territorial Planning of the Amazon: Interactions between the State and Science}

\author{
Josimara Martins DIAS* \\ Newton Müller PEREIRA**
}

\begin{abstract}
RESUMO
O presente artigo tem o objetivo de traçar considerações sobre a evolução das Unidades de Conservação em meio ao ordenamento territorial da Amazônia e, para compreender esse processo, propõe cinco períodos. Atualmente, a Amazônia brasileira é a região que detém a maior concentração de áreas protegidas no Brasil. É também a região que mais recebeu incentivos para tal prática no mundo a partir do ano 2000. Então, o presente artigo discute a conformação da função social dessas áreas protegidas em relação aos interesses locais, nacionais e internacionais mediados pelas relações estabelecidas entre o Estado e a Ciência.
\end{abstract}

Palavras-chave: Amazônia; política científica; política ambiental.

\begin{abstract}
This paper aims to present considerations on the evolution of Conservation Units amid the territorial planning of the Amazon and to understand this process proposes five periods. The Brazilian Amazon is currently the region with the largest concentration of protected areas in the country. It is also the region that has received, since 2000, the most incentives for such practices in the world. This paper additionally discusses the reshaping of the social function of these protected areas in relation to national and international interests mediated by the relationships established between the State and Science.
\end{abstract}

Key-words: Brazilian Amazon; scientific policy; environment policy.

\footnotetext{
• Geógrafa (licenciada e bacharel), doutoranda em política científica e tecnológica na Universidade Estadual de Campinas (UNICAMP). E-mail: josimaramdias@ gmail.com

** Geólogo, Pós-doutorado em Ciências Sociais Aplicadas pela Universidade de Sussex-UK. Professor do Departamento de Política Científica e Tecnológica, do Instituto de Geociências, UNICAMP. E-mail: newpe@ige.unicamp.br
} 


\section{Introdução}

O presente artigo pressupõe que para compreender a formação da política ambiental no Brasil, com foco na delimitação de áreas protegidas, é importante considerar a relação entre as ações do Estado e a contribuição da Ciência nacional. Historicamente, as políticas de delimitação e ordenamento territorial foram orientadas por (e orientaram) práticas científicas. No final do período colonial, os cientistas nascidos no Brasil e formados nas tradicionais escolas europeias eram os portadores da "razão necessária ao progresso da nação" que nascia. Esses intelectuais estavam enraizados tanto na lógica do "positivismo" quanto nos interesses da elite local, da qual faziam parte (SCHARTZMAN, 1979; PÉCAUT, 1989).

De acordo com Pádua (2004), as primeiras críticas sobre a degradação ambiental no Brasil ocorreram motivadas pelo potencial valor econômico da natureza e derivavam de uma legítima identificação entre a destruição do território e a herança colonial. Assim, a análise do processo de delimitação de áreas protegidas no Brasil suscita a necessidade de considerar a indissociabilidade entre a razão científica e a política, tanto na agenda dos intelectuais voltados à problemática da degradação ambiental quanto nas ações do Estado.

O grande agente de produção do espaço é o Estado, por meio de políticas de uso, organização e regulação do território. O Estado estabelece as normas de uso dos recursos, implanta infraestruturas essenciais e é o grande indutor da ocupação territorial, ou seja, é um mediador essencial das relações sociedade-espaço e sociedade-natureza no mundo moderno (SANTOS, 2003). Contudo, na produção do espaço, é importante levar em consideração a política da comunidade científica no jogo de forças entre os atores hegemônicos. A sociedade moderna não pode ser compreendida em sua totalidade sem levar em consideração o papel político desempenhado pela Ciência, pois, internamente à comunidade de pesquisa, existem agentes influentes na formulação e justificação de políticas públicas mediante a posse e o exercício de alguma expertise - valorizada, principalmente, quando se trata da política ambiental (PEPPER, 1984; KNORR-CETINA, 1999; BIJKER, 2003).

Um dos principais instrumentos de política ambiental é a delimitação de áreas protegidas, as quais podem ter diferentes categorias quanto ao tipo de propriedade da terra e ao formato da gestão. A função social legalmente estabelecida para essas áreas pode ser compreendida como a escolha política acerca de um conjunto de prioridades e interesses sobre a "natureza" em determinado contexto histórico. Tal escolha não está dissociada da consolidação da Ciência enquanto saber hegemônico e, sobretudo, das percepções construídas pelas Ciências Naturais para explicar os processos geradores e mantenedores do equilíbrio da paisagem e da biodiversidade.

É importante esclarecer que não se trata de negar os benefícios sociais que a Ciência moderna proporcionou, mas o conhecimento científico não é suficiente para garantir um uso racional e prudente dos recursos naturais porque não se trata de um "conhecimento neutro" de interesses, e sim da expressão de uma relação social específica com a natureza (PORTO-GONÇALVES, 1990, 2008). Conforme Pimbert e Pretty (2002), o "manual científico da conservação" é o resultado de um conjunto de escolhas sobre visões de mundo e relações de poder. Tais escolhas não são entre "florestas virgens" e "não virgens", mas entre diferentes tipos de uso e formas de controle político sobre os recursos, pois a objetividade valorizada no método preservacionista é por si mesma uma forma de selecionar e modelar a natureza.

Uma análise substancial do atual ordenamento territorial da Amazônia brasileira não pode deixar de considerar o processo histórico de organização, uso e regulação desse espaço. Castillo (2001) define que a organização do território é formada pela quantidade, qualidade e arranjo das materialidades (naturais e técnicas) presentes em cada período histórico, ou seja, uma configuração que pode facilitar ou dificultar determinados usos. Em decorrência, o uso do território se dá pelas ações efetivamente concretizadas entre as diversas possibilidades oferecidas pela organização do território herdada numa dada circunstância histórica e como resultado do jogo das forças sociais presentes. A regulação, por sua vez, é estabelecida pelo conjunto de normas (jurídicas, costumes etc.) que legitima o uso e condiciona a dinâmica e as transformações na organização do território como resultado do campo de forças entre o Estado, o mercado e a sociedade civil, na qual se inclui a comunidade científica. Assim, para definir qualquer parte do território, é fundamental considerar a interdependência e a inseparabilidade entre a materialidade - que inclui a natureza - e o seu uso - a ação humana, isto é, o trabalho e a política (SANTOS; SILVEIRA, 2001, p. 247).

Conforme Santos e Silveira (2001), a história do território brasileiro é, a um só tempo, uma e diversa, pois é também a soma e a síntese das histórias de suas regiões. Para entendê-la no seu processo e na sua realidade atual, 
é necessário um esforço de periodização. Nesse sentido, o presente trabalho propõe cinco períodos para apresentar o processo histórico de ordenamento territorial da Amazônia brasileira no que concerne à delimitação das áreas protegidas de propriedade pública destinadas à conservação da natureza. Os períodos não foram delimitados por datas ou cortes rígidos devido ao caráter difuso do ambientalismo, que envolve o jogo de forças entre ações normativas, movimentos sociais e paradigmas científicos diversos. Então, é importante destacar que não se trata de uma periodização da política ambiental como um todo no Brasil, mas sim de uma de suas vertentes de ação.

O primeiro período inicia-se no século XVIII e se estende até o final do século XIX, caracterizado pela ausência de uma política ambiental efetiva, mas com algumas iniciativas discursivas entre os intelectuais independentistas. No século XVIII, importantes intelectuais brasileiros já se manifestavam sobre a degradação ambiental no país, caracterizando-a como indiscutível fator de "atraso". Nessa época, também foram instalados Hortos Florestais no Rio de Janeiro e no Pará para a aclimatação e experimentação de espécies exóticas provenientes de várias colônias para fins agrícolas. $\mathrm{O}$ segundo período inicia-se no século $\mathrm{XX}$, com a delimitação da primeira área de preservação na Amazônia, em 1911, especificamente na área do Acre - mas a mesma não foi implementada na prática. A partir da década de 1930, também se estabelece um importante arcabouço normativo para a proteção dos recursos naturais no Brasil e, principalmente, a delimitação efetiva das primeiras áreas de preservação (enquadradas no modelo norte-americano de parques nacionais). Entretanto, de 1910 até a década de 1950, nenhum espaço de preservação foi delimitado na Amazônia brasileira.

O terceiro período inicia na década de 1960 , juntamente com as ações orquestradas pelo governo militar direcionadas para a integração territorial e captação de investimentos estrangeiros. O Estado disponibilizou uma série de incentivos para a compra de terras nas regiões centro-oeste e norte, que deveriam hospedar grandes empreendimentos desenvolvimentistas nas "terras sem homens". À margem desse planejamento, ocorria a institucionalização da política ambiental no Brasil e a implantação das primeiras áreas protegidas no bioma amazônico - ações essas motivadas por pressões de organismos internacionais contrários ao desmatamento.

O quarto período coincide com processo de abertura democrática na década de 1980 e se desdobra até o final da década de 1990, caracterizado por uma renovação na percepção científica, principalmente dos biólogos, sobre os benefícios da presença humana em áreas de preservação. $\mathrm{O}$ insucesso de muitas áreas protegidas delimitadas provocou controvérsias científicas a respeito do isolamento total da natureza, principalmente nos países pobres. Na Amazônia brasileira desdobra-se o fortalecimento político dos "povos da floresta" em busca de um modelo alternativo de desenvolvimento, apoiado, de certa forma, pelas pressões internacionais contra o desmatamento. Como resultados, nascem categorias inovadoras de áreas protegidas como, por exemplo, as "Reservas Extrativistas" (RESEX) e as "Reservas de Desenvolvimento Sustentável" (RDS). Nesse período, nota-se também o crescimento exponencial no número de áreas protegidas na região norte. Muitas foram identificadas e financiadas por programas internacionais de pesquisa focados na biodiversidade.

Finalmente, o quinto e último período se desenrola a partir da Lei 9.985, de 18/07/2000, marco legal que estabelece o Sistema Nacional de Unidades de Conservação (SNUC). Essa lei consolidou novos modelos de áreas protegidas com a função de "desenvolvimento sustentável". Destaca-se, também, o maior investimento do Estado em políticas de regularização fundiária e de delimitação de áreas protegidas. $\mathrm{O}$ Brasil foi o país no mundo que mais delimitou Unidades de Conservação após o ano 2000 e a grande maioria está justamente no bioma amazônico, conforme será apresentado no artigo.

\section{Primeiras iniciativas e objetivos da política ambiental no Brasil (XVIII e XIX)}

Desde o período colonial, há relatos de expedições enviadas da Europa para o Brasil (filosóficas e demarcatórias), para a pesquisa e extração de recursos que poderiam ser comercializados nas metrópoles, principalmente da vegetação amazônica. Havia laços explícitos que uniam o financiamento de cientistas naturalistas, os interesses geopolíticos de expansão territorial e, consequentemente, o proveito econômico das especificidades naturais. Essa relação pode ser analisada detalhadamente nos trabalhos de Sevcenko (1996), Domingues (2001), Alves (2005) e Rezende (2006).

Nos séculos XVIII e XIX, o forte interesse sobre "a complexa natureza do novo mundo" e "curiosidade científica" dos naturalistas - patrocinados por diferentes 
reis europeus (especialmente da França e da Alemanha) - motivaram Portugal a determinar a instalação de jardins botânicos em todas as suas colônias (América, África e Ásia) para aclimatar espécies exóticas com fins agrícolas. Tratava-se de uma rede de informações científicas associadas às instituições comerciais da época e à geopolítica de expansão territorial (SANJAD, 2005; LOPES, 1999).

No Brasil, a instalação desses hortos ocorreu nas duas últimas décadas do século XVIII e institucionalizou a prática de aclimatação de espécies exóticas para experimentações agrícolas e para enriquecer o acervo do Real Jardim Botânico da Ajuda ${ }^{1}$. Dessa forma, Portugal articulava uma rede de informações com naturalistas distribuídos por todas as suas colônias, que enviavam herbários, cascas de árvores, raízes, resinas, frascos com terra, sementes, peixes, caixotes com plantas, gaiolas com pássaros, animais; tabuleiros de borboletas e amostras de rochas (DOMINGUES, 2001). Com o desenrolar dessa prática, em 1796 foi determinada a criação do Jardim Botânico do Grão-Pará, o primeiro espaço oficial na região norte para a prática de investigação técnico-científica da natureza da Amazônia.

O Brasil, assim como outros países de formação colonial, tem na apropriação territorial um motivador recorrente de alianças políticas (MORAES, 2002) e as práticas científicas também não negaram tal incentivo ao participarem como peças centrais no reconhecimento das características desses territórios, encarregadas da "missão civilizatória". Os intelectuais ou "pensadores" faziam parte da elite econômica colonial, ligados por laços de parentesco sanguíneo e/ou afinidade com senhores de engenho, fazendeiros de café, comerciantes e políticos. Tais personalidades eram os porta-vozes do estamento dominante do qual faziam parte e influenciavam as ações de planejamento e ordenamento territorial (FERRI; MONTOYANA, 1981; DOMINGUES, 2000).

As primeiras iniciativas para a manutenção das florestas intactas no território brasileiro surgiram no século XVIII e se fortaleceram no século XIX. Personalidades, tais como José Bonifácio de Andrada e Silva (naturalista, poeta e ministro de Negócios Estrangeiros do governo imperial), consideravam as florestas como "um grande livro, cujo segredo e riquezas poderiam ser arrebatados pelo conhecimento científico" (BRITO, 2000, p. 53). José Bonifácio foi o fundador da crítica sistemática da destruição ambiental no Brasil, embora também houvesse outros críticos espalhados pelas diversas capitanias, a exemplo de Alexandre Rodrigues Ferreira (1756-1815) na Amazônia. Pádua (2004) destaca o caráter minoritário desse conjunto de críticos em meio à elite econômica colonial e a diversidade de suas motivações políticas, apesar das influências teóricas do positivismo europeu serem semelhantes.

Para Pádua (2004, p. 11), não é possível afirmar que a discussão ambiental é "externa" ao debate político brasileiro, pois ela acompanha a discussão sobre o destino do país desde os tempos coloniais. Para intelectuais como José Bonifácio, os recursos naturais constituíam o grande trunfo para o progresso futuro do país. O valor da natureza, dessa forma, já repousava em sua importância econômica e política. Assim, a dinâmica da natureza deveria ser decifrada pelo conhecimento científico e pela experimentação consciente e racional, que estabeleceriam as condições para o seu correto aproveitamento.

Em 1876, André Rebouças (engenheiro e abolicionista) lançou a primeira proposta para a criação de parques nacionais no Brasil, especialmente nas Sete Quedas de Guairá e na Ilha do Bananal. Essa proposta surgiu com inspiração nos parques norte-americanos, como o Yellowstone ${ }^{2}$, criado em 1872 (PÁDUA, 2004). O eixo da argumentação de Rebouças era o progresso que o turismo poderia trazer para aquelas regiões, ou seja, no Brasil o "valor estético e de contemplação" dessas paisagens foi interpretado como "valor econômico potencial". Tal perspectiva estava vinculada a uma proposta de modernidade para o país.

A problemática ambiental foi muito discutida por intelectuais, membros da elite local, que visavam a um desenvolvimento autônomo para a região de onde provinham. Alguns desses personagens, inclusive, utilizaram o tema da destruição ambiental como argumento de crítica ao colonialismo e defesa da independência através do emprego de "práticas modernas" na produção agrícola (PÁDUA,

\footnotetext{
${ }^{1}$ O Jardim da Ajuda, criado em 1768 e nutrido a partir das colônias do império ibérico, chegou a manter 5.000 espécies dispostas e aclimatadas no final do século XVIII. Esse jardim exerceu, efetivamente, o controle sobre as remessas de produtos naturais provenientes das colônias e sobre os experimentos agrícolas com vegetais exóticos. A direção do jardim importou plantas do exterior para distribuir pelos governadores do Brasil e o intercâmbio no sentido inverso também foi realizado (SANJAD, 2005).

${ }^{2}$ O Parque Yellowstone é considerado por muitos autores como o primeiro "Parque Nacional de Preservação" do mundo. O objetivo desse parque norte-americano se enquadra em uma perspectiva estética de apreciação e contemplação das paisagens naturais. Esse modelo de parque se tornou referência para a função social das áreas protegidas e do movimento "preservacionista" no mundo.
} 
2004). Contudo, esses intelectuais não lograram promover a implementação de políticas públicas para o enfrentamento efetivo da destruição ambiental, pois essa vontade chocava-se com o interesse imediato da elite econômica. Assim, nenhuma norma e/ou área protegida foi efetivamente criada no Brasil até o final do século XIX.

\section{As primeiras normas e áreas protegidas no Brasil (1900 a 1950)}

No final do século XIX e início do século XX, palavras como "civilização" e "progresso" eram comuns nos textos científicos. As ciências agrárias e médicas foram os campos que mais se destacaram e receberam incentivos. $\mathrm{O}$ fortalecimento dessas áreas estava atrelado aos projetos "evolucionistas" e "nacionalistas", com a instalação de ferrovias, linhas telegráficas, saneamento urbano, a cura das "doenças tropicais" para a ocupação dos espaços de vazios demográficos no território e à "batalha da borracha" na Amazônia3 (ARAGÓN, 1994). O papel do Estado era viabilizar o domínio territorial, dotá-lo de infraestrutura e induzir seu povoamento (MORAES, 2002). Os projetos se respaldavam no ideário cientificista de "intervenção racional para o domínio da natureza" e da autoatribuição de uma "missão civilizadora" aos intelectuais, que se viam responsáveis pela formação da nacionalidade brasileira (PÉCOLT, 1990; SCHWEICKARDT; LIMA, 2007).

Em 1911, foi publicado o primeiro "Mapa Florestal Brasileiro" com uma descrição detalhada dos diferentes biomas detectados e seus estados de conservação. Como decorrência desse trabalho, o Decreto 8.843, de 27/07/1911, foi promulgado para delimitar uma Reserva Florestal no Acre com 2,8 milhões de hectares. Segundo MEDEIROS (2006), o Decreto ficou no papel porque essa área nunca foi implementada de fato. $\mathrm{O}$ documento que comprova a existência desse Decreto foi encontrado somente na década de 1990, quando restava muito pouco da vegetação nativa do local.

Posteriormente, as aspirações preservacionistas foram importadas do modelo norte-americano e, de forma discreta, registradas na Constituição da República brasileira de 1934. No Capítulo I, Art. 10, definiu-se a responsabilidade da União de "proteger as belezas naturais e monumentos de valor histórico e artístico". A partir da década de 1930, Getúlio Vargas estruturou um aparelho de Estado modernista com normas e instituições especiais para o ordenamento territorial. Entre elas estão o Instituto Brasileiro de Geografia e Estatística (IBGE), Código das Águas (Decreto 24.643, de 10/07/1934), Código Florestal (Decreto 23.793, de 23/01/1934), Código de Proteção aos Animais (Decreto 24.645, de 10/07/1934), Código da Pesca (Decreto 794, de 19/10/1938), Código de Minas (Decreto 1.985, de 29/01/1940) ${ }^{4}$. Em 1937 é delimitado o Parque Nacional do Itatiaia, localizado na Serra da Mantiqueira, que é a primeira área protegida efetivamente implementada no Brasil, ao contrário do que ocorrera com a Reserva Florestal do Acre, decretada 26 anos antes.

Os Parques Nacionais vinculavam-se ao conceito de monumentos públicos naturais e visavam resguardar porções do território nacional com valor estético e científico - e a remoção de qualquer habitação humana era considerada obrigatória. Todavia, esses Parques foram palco de inúmeros conflitos étnicos, econômicos e políticos em vários países 5 . Tais confrontos ocorrem porque nas florestas, aparentemente vazias e intocadas, vivem populações indígenas, ribeirinhas, pescadores artesanais, entre outras sociedades tradicionais portadoras de outras culturas, com mitos próprios e relações com a natureza distintas daquelas existentes nas sociedades urbano-industriais modernas (DIEGUES, 1996). A maioria das áreas protegidas, em que pese sua importância estética e ambiental, foi delimitada

\footnotetext{
${ }^{3}$ As atividades sanitárias para viabilizar a construção de ferrovias demandavam intenso trabalho científico para identificar as formas de transmissão de importantes doenças tropicais. As coleções do "Instituto de Patologia Experimental Manguinhos", criado em 1900 (atual Instituto Oswaldo Cruz, no Rio de Janeiro), foram enriquecidas com exemplares de mosquitos, barbeiros e moluscos, trazidos da região norte. Em 1909 o médico sanitarista Oswaldo Cruz foi contratado pela Madeira-Mamoré Railway Company para realizar a profilaxia da malária e viabilizar a "ferrovia do diabo" na Amazônia, na qual morreram milhares de trabalhadores (SCHWEICKARDT; LIMA, 2007). Com relação à "batalha da borracha", na década de 1940, o governo brasileiro definiu com os EUA uma operação em larga escala de extração de látex na Amazônia para suprir as "nações amigas" durante a Segunda Guerra. O desafio do governo brasileiro era aumentar a produção de látex e, para isso, foi necessário incentivar a migração de trabalhadores para a Amazônia e criar instituições de suporte a essa produção, entre as quais estava o "Banco de Crédito da Borracha".

${ }^{4}$ Outros instrumentos normativos também foram criados durante o governo de Getúlio Vargas com o intuito de preservar a natureza no território brasileiro, que impactaram no direito de propriedade e, consequentemente, no uso do bioma amazônico. Contudo, o foco desse artigo está nas áreas protegidas públicas com a finalidade de preservação e conservação.

${ }^{5}$ De 1872 a 1877, na região do famoso parque norte-americano Yellowstone, cerca de 300 pessoas das tribos locais morreram em confronto com o exército (MORSELLO, 2001). Apesar desse saldo de mortes, o modelo norte-americano de preservação foi transposto para outros países com formações socioespaciais completamente distintas, como os países africanos e o Brasil.
} 
nas regiões economicamente menos produtivas e/ou isoladas. Às populações residentes nesses locais, consideradas cientificamente "irracionais", não foi dado nenhum poder de negociação e/ou participação na delimitação das áreas para a preservação da natureza existente em seus territórios.

Outro ponto a destacar é que, apesar da criação de um modelo para Parques Nacionais, até o início dos anos 1960 não existia um corpo bem estruturado de métodos científicos voltados para a definição das melhores áreas geográficas a serem preservadas, nem nenhum instrumento que pudesse auxiliar na delimitação do formato, do tamanho e, principalmente, da gestão das mesmas. A partir dessa década, começaram a ser estruturados os primeiros métodos pela Biogeografia, que abarcaram basicamente aspectos como os níveis de biodiversidade e/ou endemismo das espécies, mas também sofreram influência de aspectos econômicos de cada região, principalmente nos países pobres. Desde então, o caráter científico passou a exercer uma importância cada vez maior no direcionamento da política ambiental como, por exemplo, o conceito de "ilhas de preservação" (MORSELLO, 2001).

Até a década de 1960, também não havia nenhuma área de proteção implementada na Amazônia brasileira. $\mathrm{O}$ projeto para o ordenamento territorial não estava vinculado à preservação nem à contemplação das paisagens, mas sim à sua ocupação econômica. Os empreendimentos e as infraestruturas necessários à formação de um mercado nacional eram o foco das políticas de Estado ${ }^{6}$. Nesse contexto, os esforços governamentais destinados à região norte do país até a década de 1960 foram basicamente a criação de instituições de pesquisa destinadas ao avanço da agricultura moderna, como, por exemplo, a Escola de Engenharia do Pará (1931), o Instituto Evandro Chagas (1936), o Instituto Agronômico do Norte (1939) e a Escola de Agronomia da Amazônia (1945).

\section{O ordenamento desenvolvimentista e a preservação da Amazônia (1960 - 1970)}

Durante as décadas de 1960 e 70, o regime militar celebrou o "milagre econômico", consolidando a industrialização da economia por meio da instalação de infraestruturas de circulação, telecomunicações, energia e pesquisa para fomentar o "desenvolvimento das regiões deprimidas do país" (MORAES, 1997). A ação do Estado em prol do desenvolvimento econômico dessas regiões, especificamente na região norte, impactou fortemente o cenário da política ambiental brasileira nos anos seguintes, tanto pelo desmatamento desenfreado que propiciou quanto pelo contraponto que ensejou ao despertar a comunidade científica internacional para a preservação da Amazônia.

Em 1965 o Código Florestal ganhou nova versão com a Lei 4.771, de 15/09/1965. Os objetivos seguiam basicamente a mesma linha da versão de 1934; contudo, avançou com a inserção de novas categorias de áreas protegidas (Parque Nacional, Floresta Nacional, Áreas de Preservação Permanente e Reserva Legal). Dois anos mais tarde, a Lei de Proteção aos animais (5.197, de 03/01/1967) instituiu a categoria Reserva Biológica Nacional. Nesse mesmo ano, o governo militar criou também o Instituto Brasileiro de Desenvolvimento Florestal - IBDF (Decreto-Lei 289, de 28/02/1967), ligado ao Ministério da Agricultura, com jurisdição em todo o território nacional. Essa instituição estava destinada à administração de todas as áreas de preservação do país (HASSLER, 2005).

Alguns anos depois do novo Código Florestal, em meados da década de 1970, iniciou-se a expansão das áreas de preservação públicas no Brasil, principalmente na região Norte. Segundo Brito (2000), esse movimento não ocorreu somente no Brasil, pois o mundo conheceu uma impressionante expansão de áreas protegidas, com a criação de 1.300 novos parques nas décadas de 1960 e 1970, contabilizando uma ampliação de $80 \%$ - dois terços desse total se encontravam justamente nos países subdesenvolvidos. Segundo Medeiros (2006), três iniciativas internacionais patrocinadas pela UNESCO para o reconhecimento de áreas de relevante interesse ecológico e/ou cultural também contribuíram para essa expansão: "O Homem e a Biosfera", em 1970; a "Convenção sobre Zonas Úmidas”, em 1971; e a "Convenção do Patrimônio Mundial”, em 1972. O Gráfico 1 demonstra a expressiva evolução das áreas protegidas na Amazônia brasileira.

\footnotetext{
${ }^{6} \mathrm{O}$ conjunto de infraestruturas e os incentivos para ocupação territorial da região norte faziam parte de um projeto geopolítico nacionalista. Na década de 1940 , organizações internacionais já visavam à prospecção científica dos recursos naturais da Amazônia em nome de sua preservação, como o Instituto Internacional Hileia Amazônica IIHA (aprovado em 1945 pela UNESCO-ONU). Esse projeto foi recebido internamente como uma ameaça à soberania territorial do Brasil e, assim, vetado pelo Congresso Nacional. Como resposta, em 1952, Getúlio Vargas apoia a criação do Instituto Nacional de Pesquisas da Amazônia - INPA, que inicialmente foi sustentado com recursos da "Superintendência do Plano de Valorização Econômica da Amazônia - SPVEA" (ALVES, 2005).
} 


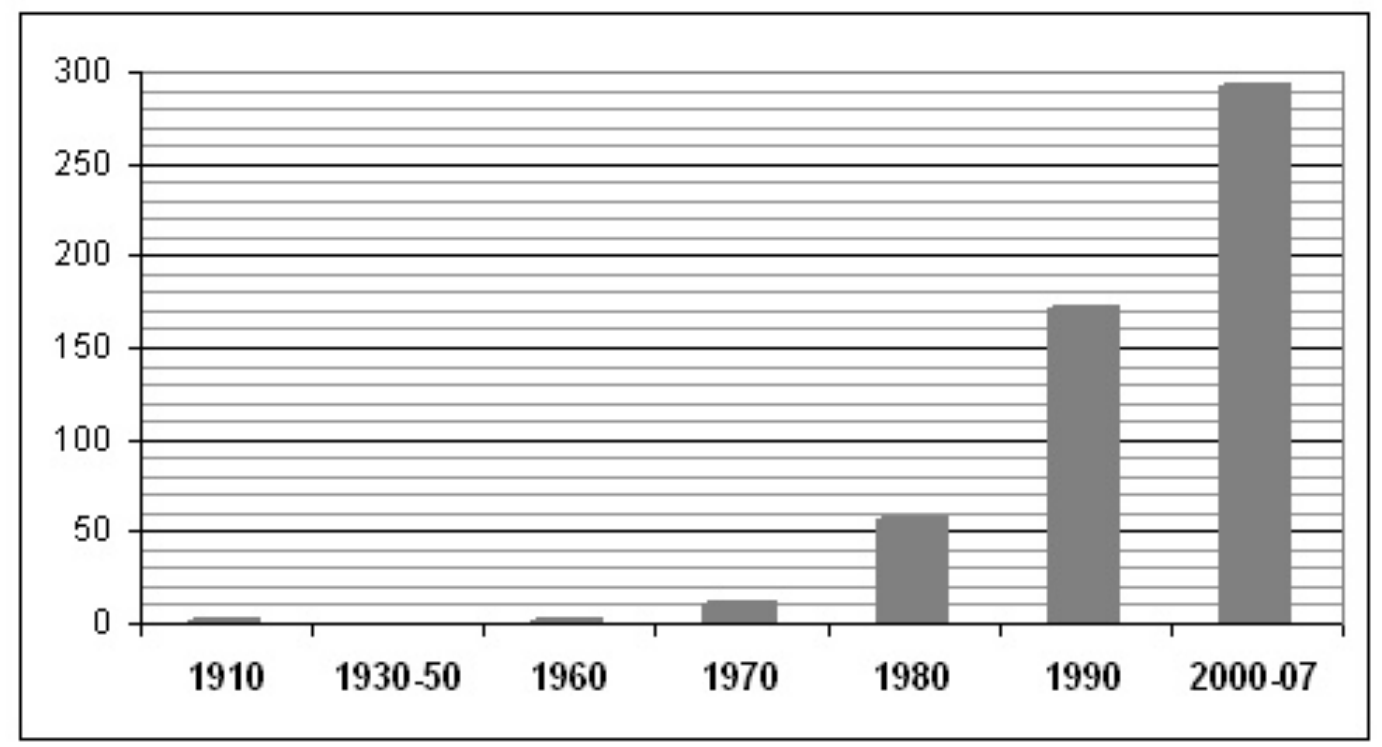

GRÁFICO 1 - ÁREAS PROTEGIDAS FEDERAIS E ESTADUAIS NA AMAZÔNIA BRASILEIRA (ATÉ JUNHO DE 2007)

FONTE: Elaboração própria a partir da revisão bibliográfica e Relatório ARPA, 2009).

Para Morsello (2001), o governo militar incentivou a avaliação técnico-científica no processo de seleção das áreas destinadas à preservação. Até então, a relevância das características científicas da biodiversidade era um critério secundário em relação ao critério da "beleza cênica da paisagem" e, principalmente, ao potencial econômico e/ ou à existência de atividades consolidadas. Muitas áreas foram escolhidas através da mera leitura de jornais ou por interesses individuais de atores influentes na política, sem nenhum critério científico específico e sem considerar a existência de populações nessas localidades (MORSELLO, 2001). Assim, a perspectiva tecnocrática vigente nos programas desenvolvimentistas do governo militar e a pressão de importantes eventos internacionais - como a conferência de Estocolmo, em 1972 - iniciaram mudanças nos métodos de seleção.

O governo brasileiro apresentou oficialmente uma posição refratária à proteção ambiental na Conferência de Estocolmo, mas a repercussão desse evento direcionou desdobramentos importantes na política ambiental nacional, como a criação da Secretaria Especial de Meio Ambiente
(SEMA) em 1973, vinculada ao Ministério do Interior. A atuação da SEMA circunscreveu-se à popularização da temática ambiental na sociedade brasileira, fomento da criação de órgãos estaduais e municipais de meio ambiente e ao aumento do número de áreas protegidas (CUNHA; COELHO, 2003). Apesar desses desdobramentos, os órgãos da política ambiental brasileira receberam pouco ou quase nenhum respaldo orçamentário para a adequada execução dos instrumentos legais criados.

Nesse período, existiam dois órgãos federais que exerciam a função de criação de áreas de preservação: SEMA e IBDF. Entretanto, os instrumentos da política ambiental se caracterizavam mais como mecanismos compensatórios em relação aos macroprojetos desenvolvimentistas de incorporação da região norte ao mercado nacional e internacional. O próprio setor público se desobrigava de respeitar as normas, a exemplo dos grandes projetos governamentais de infraestruturas territoriais, que não demandaram nenhum tipo de avaliação de impactos sociais e ambientais (MELLO, 2006) ${ }^{7}$.

\footnotetext{
${ }^{7}$ A legislação ambiental existente era desconsiderada principalmente para os empreendimentos de mineração. Em 1967 o governo militar criou a "Companhia de Pesquisas e Recursos Minerais" - CPRM, vinculada ao Ministério de Minas e Energia, para executar pesquisas e levantamentos da geologia regional, mas tais pesquisas não envolviam avaliação de impactos (OLIVEIRA, 1991).
} 
O modelo de desenvolvimento adotado pelo governo militar baseou-se em uma "colonização dirigida e distribuição de terras na Amazônia” (BECKER, 1990), com oferecimento de vantagens fiscais a empresas de capital nacional e norte-americano ${ }^{8}$. Os beneficiados podiam destinar parte ou até a totalidade do imposto de renda para investir na região norte, além de contar com linhas de crédito especiais com juros baixos. Paralelamente, foram incentivadas também migrações de mão de obra do nordeste para o norte, em especial durante a construção de infraestruturas territoriais, como as rodovias Transamazônica e Cuiabá-Santarém. O quadro se complementou com grandes projetos de mineração e garimpo, que conformaram a frente de exploração dos recursos naturais.

Terras públicas da Amazônia foram colocadas à venda em lotes de grandes dimensões pelo INCRA e/ou de particulares. Em ambos os casos, era frequente a demarcação das terras pelos novos proprietários numa extensão muito maior do que as dos lotes adquiridos. Ampliaram-se as práticas de corrupção e "grilagem" de terras públicas, tais como a venda de uma mesma terra a compradores diversos, a venda de terras indígenas e de áreas de conservação ambiental por particulares a terceiros. Entretanto, muitas áreas pleiteadas pelos empreendedores (agropecuárias, madeireiras, mineradoras, grileiros etc.) também eram habitadas por centenas de famílias (ribeirinhos e/ou caboclos, indígenas e remanescentes da economia da borracha) que foram expulsas de suas terras, enquanto milhares de quilômetros de floresta foram desmatados (LOUREIRO; PINTO, 2005) ${ }^{9}$.
A SEMA, em suas atribuições, utilizou mais princípios pragmáticos para a escolha das áreas protegidas e priorizou terras pouco férteis ou devolutas. A relevância das características biológicas ainda era considerada o último critério de desempate na seleção e delimitação. Em 1975, o IBDF publicou um relatório para demonstrar a precariedade das áreas de preservação, que continha, entre outros dados, um levantamento das localidades com conflitos fundiários. Este relatório aproveitou informações do Projeto RADAM-BRASIL ${ }^{10}$ para a elaboração de mapas com as áreas protegidas já existentes, as atividades que restringiam a instituição de novas áreas (por exemplo, as terras particulares de relevante interesse econômico e regiões com potencial mineral) e os limites geográficos da Amazônia Legal (MORSELLO, 2001) ${ }^{11}$.

No período de 1975 a 1979, estava em curso o II Plano Nacional de Desenvolvimento (II PND). A partir do relatório produzido no IBDF, esse novo plano agregou uma "Política de desenvolvimento de recursos florestais e uso racional dos solos da Amazônia". O objetivo era racionalizar a exploração madeireira, deslocando-a para as áreas de terra firme (viabilizadas pelos novos eixos rodoviários) a partir de um "sistema de florestas de rendimento condicionadas ao reflorestamento". Grandes projetos, ao invés dos pequenos, eram considerados "essenciais para evitar os desmatamentos indiscriminados e assegurar o equilíbrio ecológico da região" (M. DO PLANEJAMENTO, em 03/09/1973, apud OLIVEIRA, 1991).

\footnotetext{
${ }^{8}$ Oliveira (1991) faz uma revisão detalhada de todos os projetos empreendidos pelo governo militar para integrar a Amazônia à economia capitalista nacional e internacional, principalmente com a aliança estabelecida com os EUA (Operação Amazônia, PIN, SUDAM, SUFRAMA, PROTERRA e PND's). O argumento ideológico de "integrar para não entregar" fazia parte desse arranjo geopolítico durante a guerra fria. Na prática, segundo Oliveira (1991), as ações dos militares entregaram milhares de hectares da Amazônia para empresas norte-americanas. Anúncios convidavam para o paraíso de negócios imobiliários que seria a Amazônia a tal ponto que o título de uma propaganda era: "convite para um encontro aos pés do arco-íris, para dividir o pote de ouro".

${ }^{9} \mathrm{O}$ processo de ordenamento desenvolvimentista empreendido na região norte durante as décadas de 1960, 70 e 80 envolveu a expansão da fronteira agrícola, da fronteira urbana, frentes de exploração mineral, delimitação de áreas protegidas, migrações de trabalhadores e posseiros do nordeste e centro-sul do país, implantação de infraestruturas territoriais de circulação e comunicação. A complexidade desse processo, que culminou na atual estrutura fundiária da Amazônia, pode ser compreendida a partir dos trabalhos importantes como os de Becker (1990 e 2006), Oliveira (1991), Porto-Gonçalves (2001), Loureiro e Pinto (2005), Steinberger (2006) e Loureiro (2009).

${ }^{10}$ O programa RADAM-BRASIL ("Radar na Amazônia"), foi criado em 1970 para realizar o levantamento integrado dos recursos naturais na extensão de 1.500 .000 $\mathrm{km}^{2}$ na faixa de influência da rodovia Transamazônica, utilizando a técnica de imageamento orbital com Radar de Visada Lateral. Posteriormente, foi lançado o Decreto 76.040, de 29/07/1975, que fixou a execução desse mapeamento integrado dos recursos naturais para a totalidade do território nacional. Assim, o RADAM, coordenado pelo Ministério de Minas e Energia com recursos do Plano de Integração Nacional (PIN), desenvolveu 38 livros com informações detalhadas sobre as características naturais do território nacional (geologia, pedologia, uso do solo, vegetação e relevo) acompanhados dos respectivos mapas temáticos na escala 1:1.000.000 (fonte: <www.projeto.radam.nom.br/historico.html>, acessado em março de 2008).

${ }^{11}$ Em 1953 o governo de Getúlio Vargas criou a "Superintendência do Plano de Valorização Econômica da Amazônia" (SPVEA), com a finalidade de promover o desenvolvimento da produção agropecuária e a integração da região norte à economia nacional. Atrelado à SPVEA também foi instituída a área de planejamento denominada de Amazônia Legal, que, no governo militar, foi retificada com a criação da "Superintendência do Desenvolvimento da Amazônia" (SUDAM). Posteriormente, a área total da Amazônia legal foi alterada com a criação dos Estados do Mato Grosso e Tocantins, em 1977 e 1988, respectivamente. Atualmente, a Amazônia Legal corresponde à totalidade dos Estados do Acre, Amapá, Amazonas, Mato Grosso, Pará, Rondônia, Roraima e Tocantins e parte do Estado do Maranhão (a oeste do meridiano de $44^{\circ}$ de longitude), ocupando cerca de $61 \%$ do território brasileiro.
} 
O II PND também previa a delimitação de áreas protegidas com o intuito de "atingir o desenvolvimento sem a deterioração da qualidade de vida e sem devastar o patrimônio nacional de recursos naturais" (SEPLAN, 1975). A inclusão da meta de preservação ambiental num plano voltado ao desenvolvimento econômico foi inusitada no Brasil, tendo ocorrido como resultado das exigências de órgãos internacionais, tais como a UNESCO/ONU. Conforme Oliveira (1991), a meta também foi inserida no plano como medida paliativa, enquanto se loteava muitas outras terras no entorno dos eixos rodoviários. A criação de mais áreas de preservação foi, então, uma das soluções encontradas no planejamento desenvolvimentista da organização territorial da Amazônia, paralelamente à delimitação dos "polos de desenvolvimento" (BECKER, 1990; LOUREIRO, 2009). Contudo, apesar do estímulo para aumentar o número de áreas protegidas, pouca importância foi atribuída à regularização fundiária na região. Tal negligência contribuiu para aprofundar violentos conflitos acerca da origem da posse e as sobreposições com terras protegidas, que conformam de forma estrutural a atual configuração da Amazônia brasileira.

Enfim, é fundamental destacar que nesse período as ações desenvolvimentistas e tecnocráticas de ordenamento territorial no governo militar não observaram os interesses das populações locais (ribeirinhos e/ou caboclos, indígenas e remanescentes da economia da borracha). Tanto o desmatamento provocado pela expansão da agroindústria e dos "polos de desenvolvimento" quanto a delimitação de áreas protegidas retiraram de muitas dessas populações o direito às suas terras. Esse conflito acabou impulsionando, na década de 1980, uma renovação na política ambiental brasileira, a partir de movimentos organizados pelos "povos da floresta", respaldados por organizações não governamentais (ONGs), pela abertura democrática e, principalmente, pela revisão nos modelos de áreas de proteção ambiental.

\section{Abertura democrática e novos modelos de Unidades de Conservação (1980 - 1990)}

O intervalo das décadas de 1980 e 1990 foi denso em discussões científicas e movimentos sociais ambientalistas, que se formaram nas escalas do local ao global motivados pela problemática da integração entre conservação ambiental e inclusão social. Como reflexo desse movimento, e da necessária redemocratização do país, houve uma inflexão nas diretrizes de vários instrumentos da política ambiental.
No processo de redemocratização, novas categorias de áreas protegidas foram elaboradas para tornar esses instrumentos mais abertos à participação social e, assim, mais eficientes na proteção da natureza. A Lei 6.902, de 27/04/1981, estabeleceu duas novas categorias: as Estações Ecológicas e as Áreas de Proteção Ambiental. Essa última categoria, ao contrário de todas as demais criadas até então, possui a característica de permitir a ocupação humana. Trata-se, portanto, de uma categoria inédita no Brasil, que tem como objetivo associar, ao mesmo tempo, a conservação e o uso sustentável dos recursos naturais em zonas urbanas e/ou rurais.

O "Sistema Nacional de Meio Ambiente" (SISNAMA), criado pela Lei 6.938, de 31/08/1981, também é um referencial na inflexão da política ambiental brasileira dada a sua abrangência. Embora tenha sido aprovada no final do regime militar, essa Lei descentralizou as decisões do poder público para as esferas municipal e estadual sobre a conservação dos recursos naturais e ampliou a participação social na formulação dessas políticas. Essa mesma Lei criou também duas novas categorias de áreas protegidas: as Reservas Ecológicas, que se enquadram nos tradicionais moldes preservacionistas, e as Áreas de Relevante Interesse Ecológico (ARIES), que permitem certo grau de manejo sustentável, dependendo do tipo de ocupação e da localização da área.

Vinculado ao SISNAMA, também foi criado o "Conselho Nacional de Meio Ambiente" (CONAMA) como um órgão colegiado consultivo e deliberativo, ou seja, com a participação de representantes do governo e da sociedade civil organizada para o estabelecimento de normas relativas ao uso dos recursos naturais. O SISNAMA também agrega o "Sistema Nacional de Informações sobre o Meio Ambiente" (SISNIMA) como um instrumento de suporte à tomada de decisões. Para Mello (2006), as inovações consubstanciais do SISNAMA não são apenas técnicas, mas também políticas, por assegurar a participação de representantes da sociedade nas decisões e por aceitar a cooperação interinstitucional, possibilitando maior capilaridade para a política ambiental como um todo.

Posteriormente, em 1988, a nova Constituição brasileira inseriu em seu sistema democrático um capítulo específico sobre o "meio ambiente" (art. 255, no Capítulo VI do Título VIII), no qual se estabeleceu a divisão das responsabilidades entre o governo e a sociedade civil em relação ao "patrimônio nacional". Assim, a União assumiu explicitamente seu compromisso com a problemática 
ambiental do país ${ }^{12}$. Mas esse instrumento central, apesar de representar um novo e importante ponto de partida, não amenizou efetivamente os conflitos de regularização fundiária, de concatenação entre os objetivos dos órgãos ambientais e os demais e, principalmente, da distribuição orçamentária necessária à adequada execução das atividades atribuídas aos órgãos públicos de proteção ambiental.

No início do ano de 1989, no auge das críticas nacionais e internacionais à gestão ambiental do Brasil, aguçadas principalmente pelas queimadas na Amazônia e o assassinato de Chico Mendes, o governo Sarney criou o Instituto Brasileiro de Meio Ambiente e Recursos Naturais Renováveis (IBAMA), pela Lei 7.735, de 22/02/1989. Essa instituição nasceu com a responsabilidade de corrigir as ambivalências de funções entre os órgãos ambientais existentes e, principalmente, administrar e fiscalizar as áreas protegidas. O IBAMA fundiu as funções antes executadas pela Secretaria Especial de Meio Ambiente (SEMA), pelo Instituto de Desenvolvimento Florestal (IBDF), pela Superintendência da Borracha e pela Superintendência do Desenvolvimento e da Pesca (BRITO, 2000).

No final da década de 1980 e no transcorrer da década de 1990 - na esteira do "desenvolvimento sustentável" do relatório Brundtland (1987) e a partir dos debates realizados na "Conferência das Nações Unidas para o Meio Ambiente e o Desenvolvimento" (ECO-92), realizada em 1992, no Rio de Janeiro - divulgou-se internacionalmente a insustentabilidade do modelo de exclusão de comunidades locais e/ou sociedades tradicionais das áreas destinadas à preservação, que até então era o método científico e político mais adequado para a manutenção do "equilíbrio ambiental". Nasceram novas referências para explicar as causas do insucesso de muitas áreas protegidas no mundo no sentido de compreender o papel e a importância das sociedades tradicionais com seus modos de vida particulares - que envolvem a dependência dos ciclos naturais, conhecimento profundo dos recursos naturais, técnicas ancestrais adaptadas ao meio, simbologias e mitos específicos (POSEY, 1999, DIEGUES, 2000; PIMBERT; PRETTY, 2002).

De acordo com Lima (1996) e Brown (2002), ao longo dos anos 1990 consolidou-se internacionalmente um novo referencial científico sobre a função social das áreas protegidas, a partir da etnobiologia e de projetos denominados Integrated conservation and developments $\mathrm{e}$ Community-based Conservation. Tais projetos consideram os ecossistemas como dinâmicos e que a degradação ambiental ocorre mais intensamente quando as comunidades tradicionais são excluídas. A conservação requer uma apreciação muito sutil das influências humanas no "equilíbrio natural". Nesse contexto, o preservacionismo passou a dividir espaço com o conservacionismo na função das áreas protegidas e o termo "Unidades de Conservação" se consolidou como o mais adequado para tais instrumentos da política ambiental.

No Brasil, o movimento social organizado pelos povos seringueiros da Amazônia, com apoio de ONGs internacionais, desdobrou-se na criação de uma importante categoria de área protegida: a Reserva Extrativista (RESEX). Essa nova categoria, instituída pelo Decreto 98.987, de 30/01/1990, foi elaborada a partir de reivindicações do Conselho Nacional dos Seringueiros (CNS) ao Instituto Nacional de Reforma Agrária (INCRA). Para Steinberger (2006), tal projeto agroextrativista se vinculou à necessidade de uma "Reforma Agrária Ecológica" na Amazônia, percebida pelo INCRA como uma solução para muitos dos conflitos de terra na região. É importante destacar também que foi a primeira categoria de área protegida cuja função social foi definida a partir dos interesses de um movimento social local, ou seja, um projeto efetivamente participativo.

As RESEX podem ser consideradas como as primeiras áreas protegidas na Amazônia com o propósito de manejo sustentável da floresta. Os usuários dessas áreas se responsabilizam pelo uso sustentável a partir do "Contrato de Concessão de Direito Real de Uso Coletivo", que é assinado por uma entidade representativa de seus interesses. A implementação da RESEX pressupõe a supervisão por institutos de pesquisa públicos que possam orientar os seringueiros quanto às melhorias técnicas nas atividades agroextrativistas e na diversificação das culturas plantadas. Além dos institutos de pesquisa, atualmente essas populações também podem ser orientadas por Organizações Não Governamentais $(\mathrm{ONGs})^{13}$. Nesse ponto, é importante

\footnotetext{
${ }^{12}$ De acordo com Pinheiro (2009, p. 35), o meio ambiente também é tratado na Constituição de forma implícita e/ou atrelado a outros temas da Constituição, como o direito à vida (Art. 5. ${ }^{\circ}$ ), os bens da União (Art. 20), a função social da propriedade (Art. 170) e saúde (Art. 196 a 200 ).

${ }^{13}$ A inserção de Organizações Não Governamentais (ONGs) na Amazônia brasileira com o caráter de instituições que elaboram pesquisas e tecnologias avançou significativamente a partir da década de década de 1980 e a expressão de suas ações vinculadas às políticas públicas se consolidou na década de 1990 . Três fatores estão diretamente relacionados à expansão desses novos formatos institucionais no cenário brasileiro: o movimento ambientalista de combate à degradação ambiental pré e pós-Rio-92; a globalização com o apoio das redes de produção e transmissão de informação; e o processo de reestruturação neoliberal das atribuições do Estado,
} 
destacar, conforme aponta Porto-Gonçalves (2001 e 2006), que as ONGs contribuíram com os movimentos sociais da Amazônia - a partir de Chico Mendes e diversos movimentos indígenas - ao quebrar as mediações tradicionais com o poder público e oferecendo, assim, outras possibilidades de ação para esses sujeitos sociais se constituírem com personalidade política própria. Todavia, o poder político alcançado por essas organizações, aliado à carência em que vivem as populações na Amazônia, também torna essas populações muito suscetíveis a novas e modernas formas de "clientelismo".

Para Cunha e Coelho (2005), nesse momento a política ambiental brasileira ainda se confrontava com as prioridades dadas às políticas desenvolvimentistas, que geravam impactos ambientais negativos, principalmente nos programas "Brasil em Ação" (1996-1999) e "Avança Brasil" (2000-2003). Mas também foram estabelecidas políticas públicas indutoras de um "Desenvolvimento Sustentável" com o intuito de amortecer a degradação ambiental sem agravar as desigualdades sociais. Tais políticas foram direcionadas preferencialmente para as áreas protegidas na Amazônia e os projetos obtiveram forte apoio de organismos internacionais dedicados à conservação e à prospecção da biodiversidade.

Na década de 1990, o avanço na delimitação de áreas protegidas no bioma amazônico foi reforçado principalmente pela percepção do potencial econômico que a biodiversidade oferece e, nesse sentido, pode-se dizer que não é uma política contraditória em relação à perspectiva desenvolvimentista. A evolução técnico-científica da biotecnologia despertou a atenção nacional para as inovações tecnológicas que poderiam surgir a partir da biodiversidade, vinculando essas áreas às "vantagens comparativas" do país no cenário econômico internacional. Conforme Pimbert e Pretty (2002) alertam, o "manual da conservação" é produzido seletivamente, contabilizando também a variável dos valores comerciais atribuídos aos recursos biológicos existentes nas áreas protegidas. "Forças políticas e econômicas cada vez mais poderosas dão forma à ciência da con- servação: os técnicos, as estruturas conceituais, as questões de pesquisa, as instituições financiadoras que promovem determinadas alternativas sustentáveis e as histórias oficiais de seus sucessos" (Idem, 2002).

Becker (2006) também chama a atenção para o "capital natural de realização futura" e das demandas internacionais que se desdobraram sobre a conservação desses recursos no final do século XX. Nesse sentido, a cooperação técnico-científica internacional tem crescido significativamente na Amazônia. O envolvimento dos países desenvolvidos com os países em desenvolvimento é fundamental para algumas áreas de conhecimento, como é o caso dos estudos sobre a biodiversidade e suas aplicações econômicas (VELHO, 2005) ${ }^{14}$. A quantidade de recursos genéticos ainda desconhecidos e inexplorados encontra-se justamente nas áreas mais pobres do mundo e, nesse quesito, destaca-se o território brasileiro, onde se localiza a maior parte da floreta amazônica. Dessa forma, a Amazônia foi ressignificada nas escalas nacional e internacional como fronteira para o desenvolvimento técnico-científico, seja para a prospecção dos atributos da biodiversidade, seja para a experimentação do "desenvolvimento sustentável" nos moldes de Brundtland e a partir dos novos modelos de áreas protegidas.

O "Programa Piloto para a Proteção das Florestas Tropicais do Brasil" (PPG-7), iniciado em 1992, é um exemplo de investimentos externos para a conservação da biodiversidade brasileira, ou seja, um vetor "tecnoecológico" (BECKER, 2006). Coordenado pelo Banco Mundial, o PPG-7 foi alvo de muitas controvérsias relacionadas à gestão e ao direcionamento das pesquisas. Entre as parcerias internacionais, esse programa reúne o governo dos EUA (USAID); o Banco Mundial (KFW), o WWF (World Wildlife Fund for Nature) e o Grupo de Cooperação Técnica Alemã (GTZ). No território brasileiro, esse programa articula a Rede Mata Atlântica, o Grupo de Trabalho Amazônico (GTA), o Instituto Nacional de Pesquisas da Amazônia (INPA), o IBAMA, o Museu Paraense Emílio

que afetou diversos setores públicos. Na Amazônia, especificamente, estão presentes esses três fatores e acrescenta-se, ainda, a vinculação dessas instituições aos movimentos sociais de comunidades tradicionais (indígenas, seringueiros, caboclos, entre outros) como mediadoras dos conflitos de terra que afloraram com os projetos desenvolvimentistas empreendidos pelo governo militar.

${ }^{14}$ Velho (2005) realizou um estudo sobre a cooperação científica do Instituto Nacional de Pesquisas da Amazônia (INPA) e identificou que as relações estabelecidas com os países desenvolvidos para a produção técnico-científica são muito assimétricas. Há uma dominação dos parceiros estrangeiros no controle da agenda de pesquisa, sobre os recursos disponíveis e na apropriação dos resultados gerados, principalmente nas publicações. Evidenciou-se também, que os programas de cooperação internacional têm pouca convergência com os objetivos estratégicos dos centros de pesquisa regionais e estão ainda mais distantes das demandas e necessidades de desenvolvimento das populações locais. Entre as razões, a autora aponta que as dificuldades financeiras enfrentadas pelas instituições locais, assim como a falta de capacitação científica das mesmas, colocam-nas em uma posição frágil no processo de negociação dos projetos. Por outro lado, o Estado brasileiro também falha no controle e monitoração dessas cooperações internacionais na Amazônia, de forma a atender os interesses nacionais. 
Goeldi (MPEG), o Fundo Brasileiro para a Biodiversidade (FUNBIO), a Fundação Nacional do Índio (FUNAI), o Ministério do Meio Ambiente (MMA) e o Ministério de Ciência e Tecnologia (MCT).

Configuradas como uma rede internacional de pesquisa, as áreas temáticas apoiadas pelo PPG-7 são: uso sustentável de recursos naturais com a participação das comunidades florestais e o setor privado; conservação da biodiversidade; fortalecimento da capacidade de gestão e monitoramento ambiental; e disseminação de conhecimento. Grande parte das pesquisas apoiadas por esse programa se desenvolvem nos limites de várias Unidades de Conservação do Amazonas e Pará. Segundo Becker (2006) e Mello (2006), esse programa implementou os projetos de "Corredores Ecológicos" configurados como mosaicos de Unidades de Conservação, Terras Indígenas e Reservas Privadas.

Ao analisar grandes programas com apelo científico em prol da conservação na Amazônia, como o PPG-7, Porto-Gonçalves (2006) destaca a formação de um verdadeiro "complexo industrial-científico" de caráter dúbio na Amazônia. Para o autor, na esteira desse complexo também têm sido embutidas práticas não só de biopirataria, mas de etnobiopirataria, posto que o que se recolhe em campo são milhares de informações sistematizadas pelas comunidades camponesas, indígenas ou caboclas e a proteção jurídica de tais conhecimentos ainda é muito conflitiva e lenta. Cerca de $75 \%$ dos princípios ativos da farmacopeia mundial têm origem em plantas utilizadas pelas sociedades tradicionais, fato que demonstra a amplitude dos conhecimentos desenvolvidos e acumulados por essas populações no trato com o meio ambiente (LOUREIRO, 2009).

Em 1996, o Estado do Amazonas criou a categoria de Reserva de Desenvolvimento Sustentável (RDS), a partir da orientação de pesquisadores brasileiros participantes do projeto "Corredores Ecológicos" financiados pelo PPG-715. As duas primeiras implementadas foram as RDS Mamirauá e RDS Amanã, localizadas no Médio Solimões (área também denominada como várzea amazônica), com alto grau de biodiversidade e endemismo das espécies. Nessa região há também diversas comunidades ribeirinhas, cuja subsistência depende da pesca e do extrativismo. A categoria RDS se enquadra perfeitamente para atender as demandas de conservação, pesquisa científica e manutenção das populações locais.

As duas novas categorias, RESEX e RDS, direcionaram posteriormente a configuração normativa do Sistema Nacional de Unidades de Conservação (SNUC) e ensejaram um novo período na política de áreas protegidas no Brasil. Então, a partir de 2000, o "desenvolvimento sustentável" se consolidou como referência para solucionar os conflitos relativos à ocupação humana em áreas protegidas e a conciliação desses instrumentos da política ambiental com os objetivos de desenvolvimento econômico do país. Essa refuncionalização compatível tem se manifestado a partir da prospecção de recursos naturais para o desenvolvimento de bio e nanotecnologias e a partir de projetos técnico-científicos de agroecologia.

\section{A configuração do Sistema Nacional de Unidades de Conservação (2000...)}

O Sistema Nacional de Unidades de Conservação (SNUC), instituído pela Lei 9.985, de 18/07/2000, pode ser considerado como um novo marco de consolidação da política ambiental brasileira. O SNUC sistematiza e ordena as diferentes categorias de Unidades de Conservação federais, estaduais e municipais. Essa lei pode ser considerada como o resultado de vários debates e enfrentamentos de interesses que envolviam ambientalistas, cientistas, ONGs, populações tradicionais e organizações privadas.

O SNUC possui duas categorias centrais, as quais se ramificam em categorias específicas de Áreas Protegidas: as Unidades de Proteção Integral (Estações Ecológicas, Reservas Biológicas, Parques Nacionais, Monumentos Nacionais e Refúgios de Vida Silvestre) e as Unidades de Uso Sustentável (Áreas de Preservação Ambiental, Florestas Nacionais, Reservas Extrativistas, Reservas de Faunas, Reservas de Desenvolvimento Sustentável e Reserva Particular do Patrimônio Natural).

A principal novidade em relação à sistematização do SNUC é a definição da categoria Reserva de Desenvolvimento Sustentável (RDS). Essa categoria estabelece a valorização dos conhecimentos tradicionais na construção

\footnotetext{
${ }^{15}$ O projeto "Corredores Ecológicos", apoiado pelo PPG-7, identificou cinco áreas prioritárias para a conservação da biodiversidade na Amazônia brasileira: Corredor Central; Corredor Norte; Corredor Oeste e Corredor Sul, além da Mata Atlântica. Na Mata Atlântica foram identificados apenas dois corredores: Corredor Norte região nordeste do Brasil; Corredor da Serra do Mar - região Sudeste (AYRES, 2005).
} 
do plano de manejo; porém, o manejo sustentável deve ser pautado pelo conhecimento científico da área. Assim, o Art. 20, Parágrafo $1 .^{\circ}$, da Lei 9.985/2000 define a RDS com o objetivo de:

Preservar a natureza e, ao mesmo tempo, assegurar as condições e os meios necessários para a reprodução e a melhoria dos modos e da qualidade de vida e exploração dos recursos naturais das populações tradicionais, bem como valorizar, conservar e aperfeiçoar o conhecimento e as técnicas de manejo do ambiente, desenvolvido por essas populações.

Enquanto o Parágrafo 5..$^{\circ}$ acrescenta que:

II - É permitida e incentivada a pesquisa científica voltada à conservação da natureza, à melhor relação das populações residentes com seu meio e à educação ambiental;

IV - É admitida a exploração de componentes dos ecossistemas naturais em regime de manejo sustentável e a substituição da cobertura vegetal por espécies cultiváveis, desde que sujeitas ao zoneamento, às limitações legais e ao plano de manejo da área.

Posteriormente foi lançado o Decreto 4.340, de 22/08/2002, que regulamenta o SNUC e acrescenta a obrigatoriedade de consultas públicas precedentes à criação das Unidades de Conservação; a definição de critérios claros para a gestão compartilhada dessas áreas com Organizações Sociais de Interesse Público (OSCIP) ${ }^{16}$; critérios para seus planos de manejo; e procedimentos relacionados às populações residentes em Unidades de Proteção Integral. Dessa forma, o SNUC avança no sentido de estabelecer a obrigatoriedade de diálogo com os atores locais, ou seja, a consulta pública e democrática no processo de criação e de gestão das áreas protegidas ${ }^{17}$. Daí surgem alguns desafios ao refletir sobre as atuais categorias do SNUC: administrar o manejo destas áreas de forma sustentável, a realização de uma "participação" efetiva das comunidades locais e, principalmente, a interação dos saberes dessas populações com os saberes científicos sem o pressuposto de hierarquias.

Em 2002, durante a "Conferência Rio + 10", sediada em Johanesburgo, também foi instituído o "Programa Áreas Protegidas da Amazônia" (ARPA), cuja meta é proteger 50 milhões de hectares da Amazônia até 2012 através da criação de Unidades de Conservação. Em 2004, o programa também criou o Fundo de Áreas Protegidas (FAP), gerido pelo Fundo Nacional da Biodiversidade (FUNBIO), para garantir a sustentabilidade financeira dessas áreas no longo prazo. Até 2008 já haviam sido delimitados 22,5 milhões de hectares de novas Unidades de Conservação e, para a segunda fase do programa (2010 a 2013), está prevista a delimitação de mais 13,5 milhões de ha na Amazônia ${ }^{18}$.

Coordenado pelo Ministério do Meio Ambiente, o programa é implementado pelo IBAMA em parceria com os governos estaduais e municipais da região, contando com o apoio financeiro do Fundo Global para o Meio Ambiente (GEF), do Banco Mundial, do Banco de Cooperação da Alemanha (KfW), da WWF, da Agência de Cooperação da Alemanha (GTZ) e ONGs nacionais. Em 2008, o programa já havia apoiado a criação de 78 Unidades de Conservação (entre federais e estaduais) a partir de estudos técnicos atualmente, financia novos estudos para a identificação de outras áreas. A previsão do programa é investir, em dez anos, cerca de US\$ 400 milhões na região - desses, já foram investidos US\$ 89 milhões, segundo informações do Ministério do Meio Ambiente.

\footnotetext{
${ }^{16}$ As parcerias de ONGs com órgãos públicos foram regulamentadas a partir das Leis 9.637, de 15/05/1988 e 9.790, de 23/03/1999. A primeira estabeleceu a categoria de "Organização Social" (OS) para certificar ONGs "cujas atividades sejam dirigidas ao ensino, à pesquisa científica, ao desenvolvimento tecnológico, à proteção e preservação do meio ambiente, à cultura e à saúde” (Art. 1. ', Lei 9.637). A partir dessa certificação essas organizações podem receber benefícios do Poder Público (dotações orçamentárias, isenções fiscais etc.). A segunda criou a certificação de outra categoria específica de ONG, a "Organização da Sociedade Civil de Interesse Público" (OSCIP), que deve, entre suas finalidades de interesse social, realizar "estudos e pesquisas, desenvolvimento de tecnologias alternativas, produção e divulgação de informações e conhecimentos técnicos e científicos que digam respeito às atividades mencionadas neste artigo" (Art. 3. ${ }^{\circ}$, Lei 9.790). As parcerias entre o poder público e essas organizações se formalizam através de "Contratos de Gestão" ou "Termos de Parceria", previstos nessas duas Leis.

${ }^{17}$ De acordo com o Art. 17, Parágrafo $2 .^{\circ}$, do Decreto 4.340/2002, a "representação da sociedade civil deve contemplar, quando couber, a comunidade científica e ONGs ambientalistas com atuação comprovada na região da unidade, a população residente e do entorno, populações tradicionais, proprietários de imóveis no interior da unidade e setores privados atuantes na região".

${ }^{18}$ O Brasil foi o primeiro país a assinar a Convenção de Diversidade Biológica (CDB), em 1992, e implementou uma série de instrumentos, tais como a formalização da Política Nacional da Biodiversidade (Decreto n. ${ }^{\circ}$ 4.339/2002), a elaboração do Programa Nacional da Diversidade Biológica - PRONABIO, o Projeto de Conservação e Utilização Sustentável da Diversidade Biológica Brasileira - PROBIO, o Plano Nacional de Áreas Protegidas - PNAP - e o Programa Áreas Protegidas da Amazônia - ARPA (fonte: www.mma.gov.br/, acessado em setembro de 2009).
} 
O ARPA também apoiou a elaboração de planos de manejo e realizou oficinas de capacitação para a formação de conselhos gestores com o envolvimento das comunidades residentes no interior das Unidades de Conservação apoiadas. As prioridades do ARPA são definidas com base em informações científicas geradas pelo "Mapa de Áreas Prioritárias para a Biodiversidade", por um "Painel Científico de Aconselhamento" e cooperação técnica de organizações internacionais. Para Becker (2006), esse programa configura-se como a maior iniciativa conjunta de conservação de florestas tropicais da história. Pode-se acrescentar também que é mais um exemplo, além do PPG-7, de investimentos que, por meio do suporte técnico-científico dos países desenvolvidos, direcionam o governo brasileiro no processo de ordenamento territorial da Amazônia.

Iniciativas como o Projeto ARPA foram destacadas em 2006 na "Oitava Conferência das Partes sobre Diversidade Biológica” (COP-8), sediada em Curitiba. Após o evento, foi lançado o relatório técnico denominado Review of experience with ecological networks, corridors and buffer zones, que anunciou uma "mudança de paradigma de Unidades de Conservação". O relatório destaca que a adequada compreensão acerca da dinâmica resultante da interação entre as atividades humanas e o "meio natural" é uma questão complexa e não linear, pois as espécies podem estar adaptadas a determinadas práticas humanas seculares ${ }^{19}$. Assim, conclui que "determinar os usos mais apropriados para conservar a natureza está longe de ser fácil”, pois algumas espécies (de fauna e flora) podem estar adaptadas e dependentes de certas práticas agrícolas tradicionais (BENNETT; MULONGOY, 2006).

O relatório da COP-8 analisa as experiências de "Redes Ecológicas" que foram efetivamente implantadas em diferentes continentes (Américas Central e do Sul, Europa, Ásia e África). Esse novo modelo de conservação articula Áreas Centrais (Core Area), Corredores Ecológicos (Corridors), Zonas de Amortecimento (Buffer Zone) e Áreas de Manejo Sustentável dos recursos naturais para as populações do interior e do entorno das áreas protegidas (Sustaintable-use areas). Especialistas da renovada "Ciência da Conservação" argumentam que esse sistema de zoneamento possibilita manter todos os fluxos e processos específicos que podem beneficiar o equilíbrio da biodiver- sidade em um dado ecossistema. Em 2006, havia 82 casos de "Redes Ecológicas" na América Latina, que foram implementados a partir da década de 1990, conforme os dados da Tabela 1.

TABELA 1 - INICIATIVAS DE REDES ECOLÓGICAS NA AMÉRICA DO SUL

\begin{tabular}{l|c}
\hline \multicolumn{1}{c|}{ País } & Quantidade \\
\hline Argentina & 7 \\
\hline Bolívia & 3 \\
\hline Brasil & 14 \\
\hline Colômbia & 17 \\
\hline Chile & 3 \\
\hline Equador & 9 \\
\hline Paraguai & 3 \\
\hline Venezuela & 8 \\
\hline Casos transfronteiriços & 18 \\
\hline Total & 82 \\
\hline
\end{tabular}

FONTE: Bennett e Mulongoy, 2006.

Dados do estudo realizado por Jenkins e Joppa (2009, p. 7) demonstram que $74 \%$ de todas as Unidades de Conservação criadas no mundo a partir de 2003 estão justamente no Brasil, particularmente na Amazônia. Esses autores concluem que se trata de "um valor esmagador para um único país" e fora do Brasil a taxa de crescimento de áreas protegidas é insignificante. Em 2008, de acordo com dados do IBAMA ${ }^{20}$, a Amazônia Legal já possuía cerca de $42 \%$ de toda a sua área delimitada com algum tipo de área protegida (de Proteção Integral, de Uso Sustentável, Terras Indígenas, Áreas Quilombolas ou Áreas Militares).

No ano de 2008, a região Norte apresentava a maior concentração de Unidades de Conservação Federais, com 118 áreas delimitadas. A região Centro-Oeste - front de expansão da agroindústria e agropecuária com capitais de alta tecnologia, voltados à exportação - é justamente a área de menor concentração, com apenas 23 áreas delimitadas. Nas regiões Sul, Sudeste e Nordeste havia 38, 56 e 62, respectivamente. A Figura 1 demonstra a atual porcentagem de terras delimitadas como Unidades de Conservação (Proteção Integral e Uso Sustentável, Federais e Estaduais) nos

\footnotetext{
${ }^{19}$ As populações indígenas habitavam a Amazônia muito tempo antes de os europeus chegarem nessa terra e a distribuição dos tipos de vegetação, bem como a concentração de determinadas espécies pode ser resultado, em parte, dos vários séculos de ocupação e técnicas desenvolvidas por esses grupos tradicionais para se adaptarem ao ambiente, de tal forma que o sistema ecológico natural da Amazônia também pode ser considerado como um produto cultural (POSEY, 1999).

${ }^{20}$ IBAMA. Disponível em: <www.ibama.gov.br>. Acesso em: abril de 2008.
} 
Estados da Amazônia Legal. O Estado do Amapá se destaca com $61,90 \%$ de seu território delimitado com Unidades de Conservação. Esses dados convergem com as informações apresentadas por Jenkins e Joppa (2009) sobre a concentração de Unidades de Conservação no Brasil e, em especial, no bioma amazônico.

Entretanto, muitas das Unidades de Conservação instituídas antes e após o SNUC ainda estão sem um plano de manejo adequado ou implementado, tais como "Unidades de Papel”, ou seja, legalmente delimitadas, mas inexistentes na prática (MORSELLO, 2001; DRUMMOND; 2004; MEDEIROS, 2006). Dada a extensão territorial que essas áreas protegidas ocupam, há muitos conflitos relacionados à ausência de condições essenciais para a gestão e o manejo das mesmas (recursos humanos e financeiros, elaboração dos planos de manejo e fiscalização), conflitos quanto à propriedade das terras e desapropriações (venda e grilagem de áreas protegidas), conflitos entre os interesses e hábitos das populações locais e dos pesquisadores e/ou técnicos atuantes nessas áreas (principalmente em relação à prote- ção dos conhecimentos tradicionais) e a sobreposição com Áreas Indígenas.

A Figura 2 apresenta a classificação das áreas protegidas na Amazônia Legal e a porcentagem total de área ocupada em cada Estado. O Acre é o único Estado em que predominam as Unidades de Uso Sustentável, justamente onde foi iniciado o movimento em prol das RESEX. Com exceção do Acre e do Amapá, nos demais Estados há o predomínio de Áreas Indígenas. Aqui é importante esclarecer que as Áreas Indígenas são espaços territoriais delimitados com regimento jurídico especial e se subdividem em: Reserva Indígena, Parque Indígena e Colônia Agrícola Indígena, conforme o Estatuto do Índio - Lei 6.001, de 19/12/1973. Entretanto, de acordo com Art. 3. ${ }^{\circ}, \S 2 .^{\circ}$, do Código Florestal (Lei 4.771, de 15/09/1965), "as florestas que integram o Patrimônio Indígena ficam sujeitas ao regime de Preservação Permanente", e o Art. 3. ${ }^{\circ}$-A define que "a exploração dos recursos florestais em terras indígenas somente poderá ser realizada pelas comunidades indígenas em regime de manejo florestal sustentável, para atender a sua subsistência".

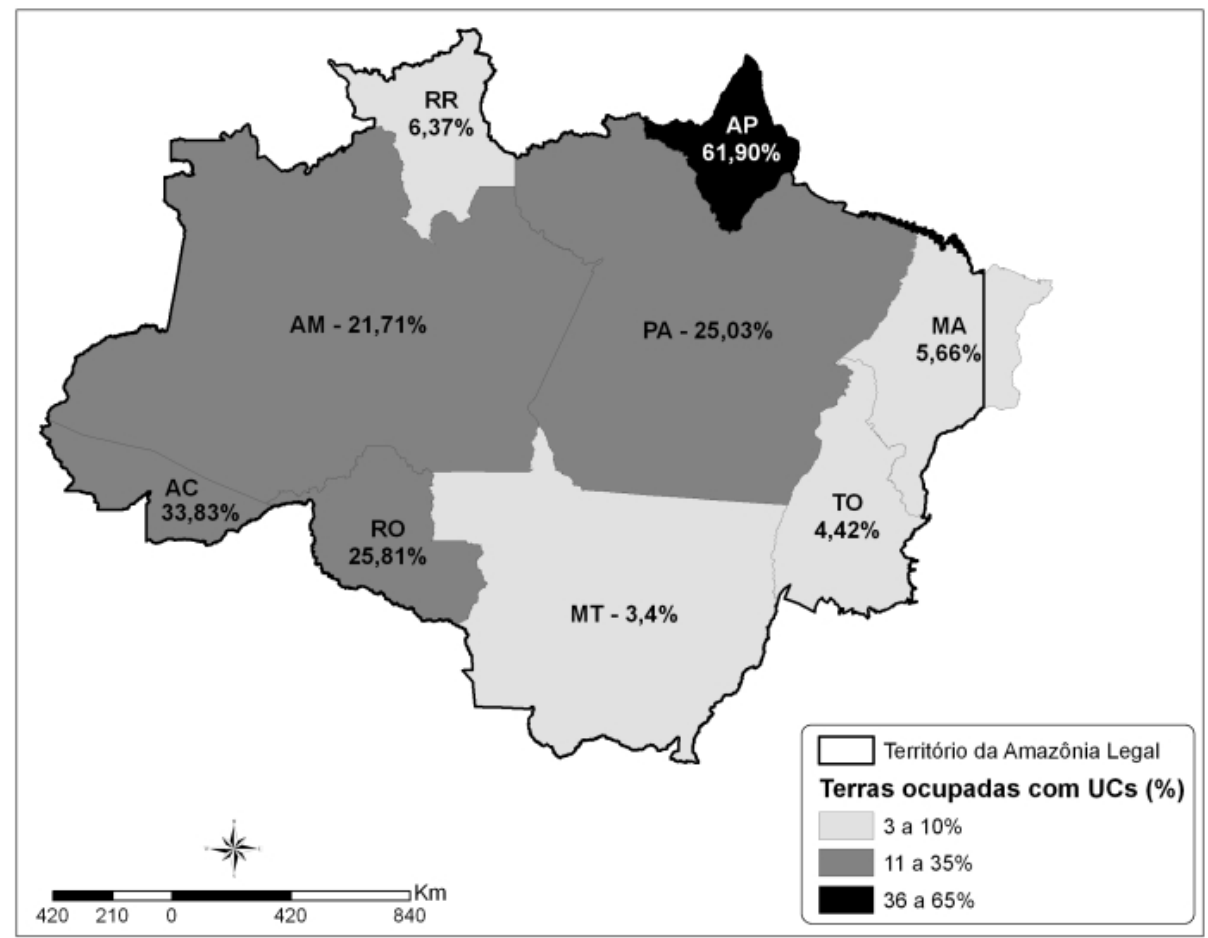

Elaboração do mapa: Josimara M. Dias. Fonte: Relatório ISA sobre o Projeto ARPA, Junho de 2009 (Disponivel em: www.socioambiental.org) FIGURA 1 - PORCENTAGEM DO TERRITÓRIO DOS ESTADOS DA AMAZÔNIA LEGAL COM ÁREAS PROTEGIDAS 


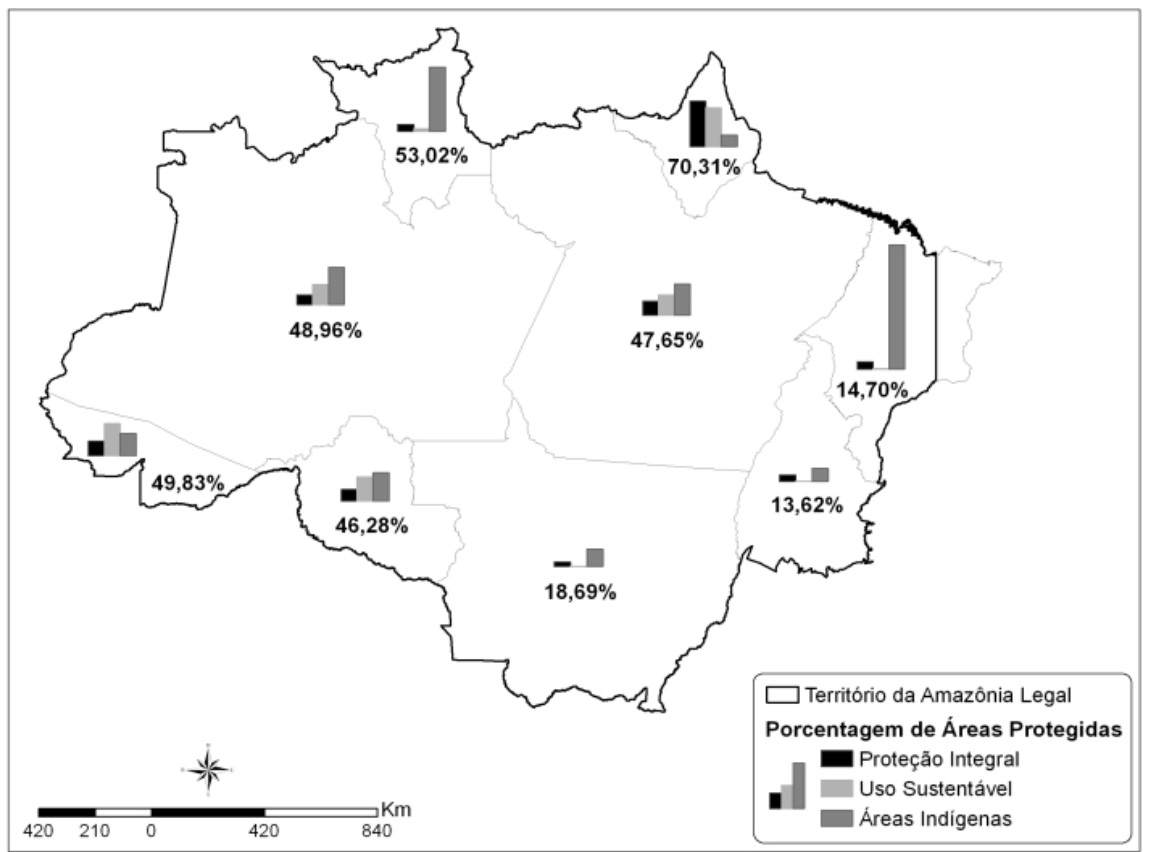

Elaboração do mapa: Josimara M. Dias. Fonte: Relatório ISA sobre o Projeto ARPA, Junho de 2009 (Disponivel em: www.socioambiental.org)

FIGURA 2 - PORCENTAGEM DE ÁREAS PROTEGIDAS POR CATEGORIA NA AMAZÔNIA LEGAL

Então, de certa forma, dada a obrigatoriedade de "manejo sustentável", podem ser consideradas como áreas protegidas que compartilham a função de conservação dos recursos naturais no território brasileiro ${ }^{21}$.

As contradições existentes entre os instrumentos legais que regulamentam essas distintas categorias de áreas protegidas se explicitam nos casos de sobreposição de áreas e dos conflitos de interesses defendidos pelos técnicos do IBAMA e da FUNAI (FANY, 2004; FALEIRO, 2005). Atualmente, existem vários casos de sobreposição entre essas áreas protegidas na Amazônia brasileira e a indefinição quanto à prevalência do regimento de um tipo sobre o outro se soma aos demais conflitos de terra deflagrados entre as comunidades tradicionais, o Estado e os interesses dos setores privados.
Com o propósito de minimizar os conflitos persistentes pós-SNUC, o governo federal criou o Plano Estratégico Nacional de Áreas Protegidas - PNAP (Decreto 5.758, de 13/04/2006). O PNAP tem a meta de "orientar as ações para o estabelecimento de um sistema abrangente de áreas protegidas ecologicamente representativas, manejadas de forma sustentável e integrar áreas terrestres e marinhas mais amplas, até 2015”. Esse Decreto destaca, entre seus princípios, o "desenvolvimento das potencialidades de uso sustentável das áreas protegidas", o "reconhecimento e fomento das diferentes formas de conhecimento e práticas de manejo sustentável dos recursos naturais" e a "sustentabilidade técnica e financeira, assegurando continuidade administrativa e gerencial na gestão das áreas protegidas".

\footnotetext{
${ }^{21}$ As primeiras Áreas Indígenas foram oficialmente delimitadas pela FUNAI a partir da década de 1980. De acordo com Art. 3. ${ }^{\circ}$, $2 .^{\circ}$ do Código Florestal (Lei 4.771, de 15/09/1965), "as florestas que integram o Patrimônio Indígena ficam sujeitas ao regime de Preservação Permanente", e o Art. 3. ${ }^{\circ}$-A da mesma define que "a exploração dos recursos florestais em terras indígenas somente poderá ser realizada pelas comunidades indígenas em regime de manejo florestal sustentável, para atender a sua subsistência". Contudo, tais disposições são contrárias à Lei 6.001, de 19/12/1973, na qual o Art. 2. , item IV, assegura aos índios "a possibilidade de livre escolha dos seus meios de vida e subsistência". A Constituição de 1988 também garante, no Art. 231, o direito das populações indígenas, apesar de não especificar se o direito de "usufruto exclusivo das riquezas do solo" nessas áreas é soberano em relação ao Art. 225 do "Meio Ambiente". Essa problemática ainda não está resolvida no Brasil e demanda um artigo específico.
} 
Em decorrência da pluralidade de interesses e atores que disputam as terras da Amazônia (econômicos, ambientais e culturais), o Ministério de Desenvolvimento Agrário também está empreendendo uma nova política de regularização fundiária na Amazônia, respaldada pela precisão proporcionada por geotecnologias. O foco principal é a regularização de 67,4 milhões de hectares nos nove Estados que integram a Amazônia, legalizando, nos próximos cinco anos, 296,8 mil posses anteriores a 2004 e com até 15 módulos fiscais (1,5 mil hectares), através do Programa "Terra Legal" (Medida Provisória 458)22. Apesar do objetivo desse programa ser exatamente a redução de conflitos de terra, sua regulamentação é polêmica na medida em que abre espaço para a legalização (uma forma de anistia) de documentos falsos que foram produzidos por meio da "grilagem".

Enfim, conforme Porto-Gonçalves (2001), hoje é possível extrair "várias e diferentes Amazônias" caracterizadas pelos distintos usos, culturas e conflitos historicamente estabelecidos. Tal especificidade também pode ser considerada como uma "resposta do território" (SANTOS, 2005) em função dos sucessivos planos políticos e técnicos de expansão territorial, ocupação e desenvolvimento econômico empreendidos desde o primeiro período proposto nesse artigo. Tais ações políticas, quase sempre respaldadas pelas percepções científicas de cada período, não levaram em consideração o fato de que essa região não era um "espaço vazio de homens" ou uma "floresta virgem" da ação humana.

\section{Considerações finais}

O artigo apresentou a evolução das áreas protegidas públicas no Brasil com destaque para as Unidades de Conservação e fez considerações acerca do processo de ordenamento territorial da Amazônia. A partir de uma revisão bibliográfica, acrescida de dados primários e secundários, o artigo propõe que a evolução das áreas protegidas públicas no Brasil pode ser explicada em cinco períodos e que essa evolução não está dissociada das relações estabelecidas entre os interesses do Estado e da Ciência.

As primeiras iniciativas de preservação no Brasil já ocorriam no primeiro período (séculos XVIII e XIX), mas as primeiras áreas protegidas foram delimitadas somente no segundo período (1900 a 1950). Ao contrário dos tradicionais parques norte-americanos, as primeiras experiências no Brasil não visavam à apreciação das belezas cênicas e o valor espiritual de suas paisagens, mas sim o potencial econômico dessas paisagens para atividades turísticas, enquanto a semelhança residia na remoção de qualquer agrupamento humano dessas áreas. Com a evolução técnico-científica ao longo do século XX, o potencial econômico dos recursos naturais existentes nessas áreas se ampliou cada vez mais.

$\mathrm{O}$ adensamento de áreas protegidas na Amazônia cresceu exponencialmente a partir do terceiro período (1960 a 1970), principalmente na segunda metade da década de 1970. Pode-se dizer que a criação dessas áreas protegidas foi uma das soluções encontradas no governo militar para o ordenamento territorial face às críticas empreendidas internacionalmente contra os desmatamentos causados pelas ações desenvolvimentistas, tais como a expansão da fronteira agrícola, exploração mineral e rodovias. Entretanto, esse processo não foi acompanhado de uma política adequada de regularização fundiária, característica estrutural que contribuiu para ampliar os conflitos de posse e/ ou sobreposição de terras na Amazônia.

A ótica preservacionista (pautada na exclusão das populações tradicionais) prevaleceu nas diretrizes da política ambiental brasileira até o terceiro período. Assim, a maior participação social na gestão e/ou habitação dessas áreas só foi aceita nas décadas de 1980 e 90, após uma revisão teórica acerca dos resultados da interação "homem-meio", que conformou o quarto período. Tal revisão evoluiu em relação às variáveis envolvidas na dinâmica de formação e manutenção de um dado bioma, incluindo a possibilidade de contribuição das práticas tradicionais de populações locais, tais como as comunidades indígenas. Essa nova perspectiva tem em sua conta os violentos conflitos que se desdobravam da expulsão dessas populações de seus meios. A partir dessa percepção científica, os pressupostos do "desenvolvimento sustentável” foram atrelados às áreas protegidas.

A redemocratização na política nacional, na década de 1980, também contribuiu significativamente para a criação de espaços e instituições com maior participação social. Até a década de 1970, os interesses das populações tradicionais - autodenominadas de "povos da floresta" - não foram considerados tanto na expansão dos projetos desenvolvi-

${ }^{22}$ MINISTÉRIO DO DESENVOLVIMENTO AGRÁRIO. Disponível em: <www.mda.gov.br>. Acesso em: em junho de 2009. 
mentistas quanto na delimitação das áreas de preservação permanente. Tal violência contribuiu para impulsionar uma renovação na política ambiental brasileira, que possibilitou a criação de categorias como as RESEX e as Reservas de Desenvolvimento Sustentável.

A partir da década de 1990, ocorreu uma "marcha para o norte do Brasil" em relação à criação de áreas protegidas. Entre os fatores diretamente relacionados a essa expansão está o potencial econômico futuro da biodiversidade para o desenvolvimento econômico, ou seja, essas áreas passaram a ser consideradas como "laboratórios naturais" estratégicos ao invés da pura preservação e contemplação das paisagens. Em 2000, o governo federal institui o Sistema Nacional de Unidades de Conservação, sistematizando dois conjuntos centrais de categorias: as "Unidades de Proteção Integral" (nos moldes tradicionais) e as "Unidades de Uso Sustentável" (novos modelos). Esse instrumento normativo marca o início do quinto e atual período, no qual o Brasil se conforma como o país que mais criou áreas protegidas no mundo. Salienta-se que seis dos sete Estados pertencentes à região norte possuem mais de $40 \%$ de seus territórios

\section{Referências}

ALVES, J. J. A. (Org.). Múltiplas faces da História das Ciências na Amazônia. Belém: EDUFPA, 2005.

ARRUDA, R. Populações tradicionais e a proteção dos recursos naturais em Unidades de Conservação. Revista Ambiente \& Sociedade, ano II, n. 5, p. 79-92, 1999.

AYRES, M. Os corredores ecológicos das florestas tropicais do Brasil. Belém: Sociedade Civil Mamirauá, 2005.

BECKER, B. K. Amazônia. São Paulo: Ática, 1990.

. Amazônia: geopolítica na virada do III milênio. Rio de Janeiro: Garamond, 2006.

BENNETT, G.; MULONGOY, K. J. Review of experience with Ecological Networks, Corridors and Buffer Zones. Montreal: Secretariat of the Convention on Biological Diversity. Technical Series, n. 23, 2006.

BIJKER, W. E. The need for public intellectuals: a space for STS. Science, Technology \& Human Values, v. 28, n. 4, p. 1-5, 2003.

BROWN, K. Innovations for conservation and development. The Geographical Journal, v. 168, n. 1, p. 6-17, 2002. delimitados com algum tipo de área protegida (incluindo as áreas indígenas, nas quais também é priorizada a prática de manejo sustentável dos recursos naturais).

As áreas protegidas na Amazônia também contam com o apoio de redes internacionais de pesquisa, como as que estruturam o PPG-7 e o ARPA. Essas redes se formaram para a prospecção dos recursos naturais, que podem se transformar em futuras inovações tecnológicas, e para a experimentação de projetos de desenvolvimento sustentável com as populações residentes no interior das "Unidades de Conservação de Uso Sustentável”. Então, resta saber qual desses dois projetos - prospecção da biodiversidade e experimentação de "ilhas de desenvolvimento sustentável" - vai se aliar mais às necessidades das comunidades residentes no interior e/ou entorno dessas áreas protegidas. Esse é mais um tema complexo atrelado às formas de uso, organização e regulação da Amazônia brasileira, que demanda mais um artigo próprio para a discussão aprofundada sobre as relações entre os interesses dos cientistas que atuam nessas áreas e os interesses e saberes das populações locais.

BRITO, Maria C. W. UCs: intenções e resultados. São Paulo: Annablume/FAPESP, 2000.

CASTILLO, R. A. Tecnologias da informação e os novos fundamentos do espaço geográfico. In: DOWBOR, L. et al. Desafios da comunicação. Petrópolis: Vozes, 2001.

CASTRO, E.; PINTON, F. (Orgs.). Faces do trópico úmido. Conceitos e questões sobre desenvolvimento e meio ambiente. Belém: Cejup-UFPA, 1997.

CHAVES, M. DO P. S. R.; NOGUEIRA, M. G. Propriedade intelectual, globalização e desenvolvimento: uma reflexão sobre os caminhos para o desenvolvimento sustentável da Amazônia. Revista Desenvolvimento e Meio Ambiente, Curitiba, n. 18, p. 115-128, 2008.

COY, M.; KOHLHEPP, G. (Orgs). Amazônia sustentável: desenvolvimento entre políticas públicas, estratégias inovadoras e experiências locais. São Paulo: Garamond, 2005.

CUNHA, L. H.; COELHO, M. C. N. Política e gestão ambiental. In: CUNHA, S. B.; GERRA, J. T. (Orgs.). A questão ambiental: diferentes abordagens. Rio de Janeiro: Bertrand, 2003. 
DIEGUES, A. C. (Org.). Etnoconservação: novos rumos para a proteção da natureza nos trópicos. São Paulo: Hucitec, 2000.

DOMINGUES, A. Para um melhor conhecimento dos domínios coloniais: a constituição de redes de informação no Império português em finais do Setecentos. Revista História, Ciências, Saúde-Manguinhos, v. 8, suplemento, p. 823-838, 2001.

DRUMMOND DE C., P. F. Ciência e gestão em Unidades de Conservação: o caso do Parque Estadual Turístico do Alto do Ribeira (PETAR), SP. Dissertação (Mestrado) - IG-DPCT-UNICAMP. Campinas, 2004.

FALEIRO, R. P. UCs versus Terra Indígena. Um Estado em conflito: estudo das influências na gestão pública. Dissertação (Mestrado) - PPGAS-ICS-UnB. Brasília, 2005.

FANY, R. (Org.). Terras Indígenas e Unidades de Conservação da Natureza: o desafio das sobreposições. São Paulo: Instituto Socioambiental, 2004.

FURNIVAL, A. C. M. Investigando o papel de cientistas em estratégias para o desenvolvimento sustentável local: visões e perspectivas da comunidade científica. Tese (Doutorado) DPCT-IG-UNICAMP. Campinas, 2001.

HASSLER, M. L. A importância das Unidades de Conservação no Brasil. Revista Sociedade \& Natureza, Uberlândia, v. 17, p. 79-89, 2005.

IUCN. The IUCN Protected Area Management Categories. Cardiff University, 2002. Disponível em: <www.iucn.org>. Acesso em: nov. 2007.

JENKINS, C. N.; JOPPA, L. Expansion of the global terrestrial protected area system. Biological Conservation, v. 142, p.1-20, 2009.

KNORR-CETINA, K. Epistemic cultures: how the sciences make knowledge. Cambridge: Harvard University Press, 1999.

LOUREIRO, V. R.; PINTO, J. N. A. A questão fundiária na Amazônia. Revista Estudos Avançados, São Paulo, v. 19, n. 54, p. 77-98, 2005.

LOUREIRO, V. R. A Amazônia no século XXI: novas formas de desenvolvimento. São Paulo: Empório do Livro, 2009.

MEDEIROS, R. Evolução das tipologias e categorias de áreas protegidas no Brasil. Revista Ambiente \& Sociedade, v. 9, n. 1, p. 41-64, 2006.

MELLO, N. A. Políticas territoriais na Amazônia. São Paulo: Annablume, 2006.

MORAES, A. C. Robert. Território e História no Brasil. São Paulo: Hucitec, 2002.
MORSELLO, C. Áreas protegidas públicas e privadas: seleção e manejo. São Paulo: Annablume/FAPESP, 2001.

OLIVEIRA, A. Umbelino de. Integrar para (não) entregar: políticas públicas e Amazônia. Campinas: Papirus, 1991.

PÉCAUT, D. Entre le peuple et la nation: les intellectuels et la politique au Brésil. Paris: Fondation de la Maison des Sciences d'Homme, 1989.

PEREIRA, D. Barros. Paradoxo do papel do Estado nas Unidades de Conservação. In: ZHOURI, A.; LASCHEFSKI, K.; PEREIRA, D. B (Orgs). A insustentável leveza da politica ambiental: desenvolvimento e conflitos socioambientais. Belo Horizonte: Autêntica, 2005.

PIMBERT, M. P.; PRETTY, J. N. Parques, comunidades e profissionais: incluindo "participação" no manejo de áreas protegidas. In: DIEGUES, A. C. (Org.). Etnoconservação: novos rumos para a proteção da natureza nos trópicos. São Paulo: Hucitec, 2000.

PINHEIRO, C. Direito Ambiental. São Paulo: Saraiva, 2009.

PLANO AMAZÔNIA SUSTENTÁVEL: Diretrizes para o Desenvolvimento Sustentável da Amazônia Brasileira. Brasília: MIN/MMA, 2008.

PORTO-GONÇALVES, C. W. Os (des) caminhos do meio ambiente. São Paulo: Contexto, 1990. . Amazônia, Amazônias. São Paulo: Contexto, 2001. . A globalização da natureza e a natureza da globalização. Rio de Janeiro: Civilização Brasileira, 2006.

Temporalidades amazônicas: uma contribuição à Ecologia Política. Revista Desenvolvimento e Meio Ambiente, Curitiba, n. 17, p. 21-31, 2008.

POSEY, D. A. Cultural and Spiritual Values of Biodiversity. London: UNEP/Intermediate Technology Publications, 1999.

REZENDE, T. V. F. de. A conquista e ocupação brasileira no periodo colonial: a definição das fronteiras. Tese (Doutorado) - USP-FFLCH. São Paulo, 2006.

RYLANDS, A. B. UCs brasileiras. Revista Megadiversidade, v. 1, n. 1, p. 27-35, 2005.

SANTOS, M. Economia espacial. São Paulo: Edusp, 2003.

. O retorno do território. In: SANTOS, M.; SOUZA, M. A.; SILVEIRA, M. L. (Orgs.). Território: globalização e fragmentação. São Paulo: Hucitec, 2005.

; SILVEIRA, M. L. O Brasil: território e sociedade no início do século XXI. São Paulo: Record, 2001. 
STEINBERGER, M. (Org.). Território, ambiente e políticas públicas espaciais. Brasília: Paralelo 15/LGE, 2006.

SEVCENKO, N. O front brasileiro na guerra verde: vegetais, colonialismo e cultura. Revista USP, São Paulo: USP, n. 30, 1996.

SCHARTZMAN, S. A formação da comunidade científica no Brasil. São Paulo: FINEP, 1979.

TEIXEIRA, Cristina. O desenvolvimento sustentável em UCs: a naturalização do social. Revista Brasileira de Ciências Sociais, v. 20, n. 59, p. 51-66, 2005.

TERBORGH, J. et al. Tornando os parques eficientes. Estratégias para a conservação da natureza nos trópicos. Curitiba: UFPR/Fund. O Boticário, 2002.

VELHO, L.; GAMA, W. A cooperação científica internacional na Amazônia. Revista Estudos Avançados, v. 19, n. 54, p. 205-224, 2005.

ZHOURI, A.; PEREIRA, D. B. (Orgs.). A insustentável leveza da política ambiental - Desenvolvimento e conflitos socioambientais. Belo Horizonte: Autêntica, 2005.

\section{Legislação}

BRASIL. Lei n. 4.771, de 15 de setembro de 1965. Institui o Código Florestal Brasileiro. Disponível em: <www.planalto. gov.br/ccivil_03/Leis/L4771.htm, outubro de 2009>.

BRASIL. Lei n. 5.197, de 03 de janeiro de 1967. Institui o Código de Proteção aos Animais Disponível em: <www. planalto.gov.br/ccivil_03/Leis/L5197.htm, outubro de 2009>.

BRASIL. Decreto-Lei in. 289, de 28 de fevereiro de 1967. Cria o Instituto Brasileiro do Desenvolvimento Florestal. $<$ Disponível em: www.siam.mg.gov.br>. Acesso em: out. 2009.

BRASIL. Lei n. 6.001, de 19 de dezembro de 1973. Regula a situação jurídica dos índios ou silvícolas e das comunidades indígenas no Brasil. Disponível em: <www.planalto.gov.br/ ccivil/leis/L6001.htm>. Acesso em: out. 2009.
BRASIL. Lei n. 6.902, de 27 de abril de 1981. Dispõe sobre a criação de Estações Ecológicas, Áreas de Proteção Ambiental e dá outras providências. Disponível em: $<$ www.planalto.gov. br/ccivil_03/Leis/L6902.htm>. Acesso em: out. 2009.

BRASIL. Lei n. 6.938, de 31 de agosto de 1981. Dispõe sobre a Política Nacional do Meio Ambiente, seus fins e mecanismos de formulação e aplicação. Disponível em: <www.planalto.gov. br/ccivil_03/Leis/L6938.htm>. Acesso em: out. 2009.

BRASIL. Lei n. 7.735, de 22 de fevereiro de 1989. Dispõe sobre a extinção de órgão e de entidade autárquica, cria o Instituto Brasileiro do Meio Ambiente e dos Recursos Naturais Renováveis. Disponível em: < www.planalto.gov.br/ccivil/leis/ L7735.htm>. Acesso em: out. 2009.

BRASIL. Lei n. 9.985, de 18 de julho de 2000. Regulamenta o art. 225, § 1. ${ }^{\circ}$, incisos I, II, III e VII da Constituição Federal, institui o Sistema Nacional de Unidades de Conservação da Natureza. Disponível em: <www.planalto.gov.br/ccivil_03/ Leis/L9985.htm>. Acesso em: out. 2009.

BRASIL. Decreto n. 8.843, de 27 de julho de 1911. Institui a Reserva Florestal do Antimary. In: MEIRA, J. de Castro. Direito Ambiental. Disponível em: $<$ http://bdjur.stj.gov.br $>$. Acesso em: out. 2009.

BRASIL. Decreto n. 24.643, de 10 de julho de 1934. Decreta o Código de Águas. Disponível em: <www.planalto.gov.br/ ccivil_03/decreto/d24643.htm>. Acesso em: out. 2009.

BRASIL. Decreto n. 23.793, de 23/01/1934. Institui o Código Florestal Brasileiro. Disponível em: <www.planalto.gov.br/ ccivil_03/Decreto/1930-1949/D23793.htm>. Acesso em: out. 2009 .

BRASIL. Decreto n. 4.340, de 22 de agosto de 2002. Regulamenta artigos da Lei n. 9.985, de 18 de julho de 2000, que dispõe sobre o Sistema Nacional de Unidades de Conservação da Natureza - SNUC. Disponível em: <www.planalto.gov.br/ ccivil_03/Decreto/2002/ D4340.htm>. Acesso em: out. 2009.

BRASIL. Decreto n. 5.758, de 13 de abril de 2006. Disponível em: <www.planalto.gov.br/ ccivil_03/_Ato2004-2006/2006/ Decreto/D5758.htm>. Acesso em: out. 2009.

Recebido em novembro de 2009. Aceito em junho de 2010. Publicado em dezembro de 2010. 